\title{
Senil og dement
}

\section{Demens er omtalt som vårt største helseproblem. Da gjelder det å ha orden på begrepene.}

Allmennspråket er mindre presist enn fagspråket. I dagligtale kan man si at en person er senil, men det man egentlig mener er at vedkommende er dement. Per Egil Hegge hevder i Aftenpostens språkspalte at man ikke legger noe nedsettende i det - senil er «bare et lettfattelig og enkelt uttrykk for at personens åndsevner var bedre tidligere», mener han (1).

Vi har inntrykk av at denne feilaktige bruken av senil er på retur i dagligspråket. Mange bruker nå heller den korrekte termen demens - kanskje på grunn av økt omtale i massemediene og fordi senil oppfattes som belastende. Inntrykket bekreftes også ved et søk i det digitale Nasjonalbiblioteket, som viser at bruken av demens har økt kraftig fra 1990-årene, mens senil er blitt mindre brukt i samme periode (2).

\section{Senil betyr gammel}

At feilen har vært utbredt, finner vi eksempel på også i leksikonet. En av våre mest fremtredende historikere skriver der om en konge at han var «gammel, senil og barnløs» (3). Meningen er nok at kongen var gammel, dement og barnløs. Ordvalget er uheldig.

I Bokmålsordboka defineres senil som «(ånds)svekket av alderdom» (4). I medisinsk fagspråk innebærer imidlertid bruken av senil ingen vurdering av åndsevnene. Ordet er avledet av latin senex, som kort og godt betyr gammel. Senex har gitt oss nyttige ord som senat (eldreråd) og senior (eldre). I medisinen er det en hærskare av sammensetninger med senil, som senil kløe, senil tremor, senil vorte - tilstander som kan komme i alderdommen.

\section{Demens}

Tradisjonelt har medisinere omtalt demens som rammer eldre med begrepene senil demens (skrevet i to ord), aldersdemens (skrevet i ett) eller dementia senilis. Ingen av dem er gode. Demens forårsakes ikke av høy alder, alder er kun en viktig risikofaktor. Man måtte være over 65 år for å få diagnosen senil demens. Var man yngre, kaltes det presenil demens.

I løpet av de siste årene er dette blitt utdaterte termer. I ICD-10-kriteriene, som kom i bruk i 1990-årene, står riktignok både presenil og senil demens (F03) (5), men vi regner med at dette vil bli endret i ICD-11, som etter planen skal lanseres i 2018 (6).

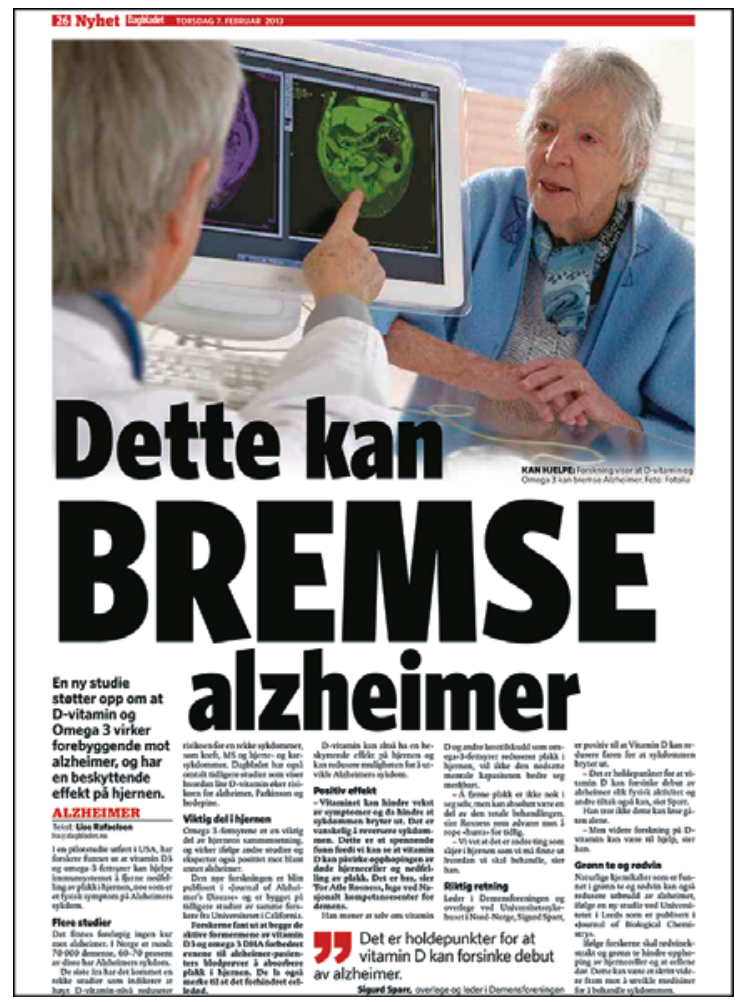

Figur 1 Mange egennavn blir etter hvert fellesnavn (13), men det gjelder ennå ikke for Alzheimers sykdom. Det er derfor galt å skrive Alzheimer med liten a. Faksimile fra Dagbladet (11)

Moderne nomenklatur er demens med tidlig eller sen debut. Fortsatt settes grensen ved 65 års alder, men det er historisk betinget, ikke vitenskapelig (7).

Omtalen av personer med demens er et eksempel på at etymologien spiller liten rolle for moderne ordbruk. Historisk henger demens sammen med det latinske ordet mens, som betyr sinn, forstand. Direkte oversatt betyr altså demens avsindig. Slike konnotasjoner er borte i dag.

\section{Lewy-legemer eller lewylegemer?}

Alzheimers sykdom er den hyppigste årsaken til demens og utgjør omtrent to tredeler av tilfellene. En mindre gruppe er demens med Lewy-legemer, som rammer ca. $15 \%$. På norsk kan man skrive det på flere måter: demens med Lewy-legemer, demens med lewylegemer, lewylegemesykdom, lewylegemedemens osv. Hvis vi velger den første måten, med bindestrek, fremkommer det tydelig at sykdommen er et eponym, den har navn etter den tyske nevrologen
Friedrich Heinrich Lewy (1885-1950), som først beskrev disse legemene (8).

Mennesker med lewylegemesykdom utvikler kognitiv svikt sammen med psykose og parkinsonisme (9). Det er uvanlig å si at man er plaget med sine lewylegemer, men i en artikkel i VG nylig sto nettopp det om en amerikaner som døde året før: «Da hadde han i lengre tid vært plaget med Lewy-legemer» (10). Det gir liten mening det er naturligvis den kognitive svikten, psykosen og parkinsonismen som plager pasientene. Tilsvarende snakker man heller ikke om at man ved Alzheimers sykdom er plaget av amyloide plakk (tidligere kalt senile plakk), selv om det er et viktig nevropatologisk kjennetegn ved sykdommen.

Alzheimer, Alzheimers og alzheimer Også Alzheimers sykdom er et eponym sykdommen har navn etter den tyske legen Alois Alzheimer (1864-1915). I dagsaviser kan Alzheimers sykdom være skrevet som «Alzheimers» eller «Alzheimer». Når det 
i en nekrolog sto at avdøde de siste årene var «plaget av Alzheimer», vil det nok for en del lesere oppfattes som litt vel bokstavelig.

En annen nyskapning er å skrive Alzheimer med liten a, for eksempel «Dette kan bremse alzheimer» og «Vaksine mot alzheimer kan være på vei» (11-13) (fig 1). Disse skrivemåtene - Alzheimer, Alzheimers og alzheimer - er slangpreget og anbefales ikke.

\section{Erlend Hem}

erlend.hem@medisin.uio.no

Tor Atle Rosness

Erlend Hem (f. 1970) er dr.med., fagsjef i Klinikk psykisk helse og avhengighet, Oslo universitetssykehus, og redaktør for Tidsskriftets språkspalte.
Tor Atle Rosness (f. 1976) er sykehjemslege i Bærum kommune, førsteamanuensis ved Lovisenberg Diakonale Høgskole og medisinsk redaktør i Tidsskriftet.

\section{Litteratur}

1. Hegge PE. «En dement person». Aftenposten 20.7.2013: 4 .

2. Senil, demens. NB N-gram beta. Nasjonalbiblioteket. www.nb.no/sp_tjenester/beta/ngram_1/ \#ngram/query?terms=senil\%2C+demens\& lang=all\&case_sens $=0 \&$ freq $=$ rel $\&$ corpus $=$ bok (31.8.2015).

3. Mykland K. (13.2.2009). Christian August. I: Norsk biografisk leksikon. https://nbl.snl.no/Christian_ August (31.8.2015).

4. Senil\%. I: Bokmålsordboka og Nynorskordboka. www.nob-ordbok.uio.no/perl/ordbok.cgi?OPP= senil\%25\&ant_bokmaal=5\&ant_nynorsk=5\&begge $=+\&$ ordbok=bokmaal (31.8.2015).

5. Helsedirektoratet medisinske kodeverk - ICD-10 https://finnkode.helsedirektoratet.no (31.8.2015).
6. International Classification of Diseases (ICD) World Health Organization. www who.int/ classifications/icd/en/ (31.8.2015).

7. Rosness TA, Haugen PK, Engedal K. Når demens rammer unge. Tidsskr Nor Legeforen 2011; 131: 1194-7.

8. Jansen J. (13.2.2009). Lewylegemer. I: Store medisinske leksikon. https://sml.snl.no/lewylegemer (31.8.2015)

9. Engedal K. (13.2.2009). Aldersdemens. I: Store medisinske leksikon. https://sml.snl.no/ aldersdemens (31.8.2015).

10. Husby M. Her er radiokjendisens anonyme grav i Oslo. VG 2.7.2015. www.vg.no/rampelys/ hollywood/her-er-radiokjendisens-anonyme-gravi-oslo/a/23481630 (31.8.2015).

11. Rafaelsen L. Dette kan bremse alzheimer. Dagbladet 7.2.2013: 26 .

12. Lauritzen C. Vaksine mot alzheimer kan være på vei. Dagbladet 20.8.2012: 6

13. Vannebo KI. Fra egennavn til fellesnavn: Klondyke, Kneipp og Quisling. Oslo: Cappelen Damm, 2014. 